\title{
SUPPORTING SUSTAINABILITY AND REDUCING INEQUALITY: IS THERE A CONFLICT BETWEEN THEM?
}

\author{
Frances STEWART
}

This paper explores the relationship between inequality and sustainability both of which are dominant considerations today. Inequality was an important preoccupation of Kaldor, although he was not concerned with sustainability, as this has only recently become an all-important issue. The paper identifies relevant criteria for determining the desirable distribution of incomes from a sustainability perspective, including considerations of justice and of instrumentality. It concludes that justice demands much greater equality of emissions (and incomes) among individuals, given that the total "safe" global emissions of carbon dioxide are limited. Instrumental considerations are not so clear-cut, as evidence suggests that sometimes greater inequality leads to reduced emissions. However, meta considerations, including motivations for pursuing economic growth and conditions likely to realise international agreements on restraining emissions, suggest that more equality within and between countries is needed to promote sustainability.

Keywords: sustainability, inequality, economic growth

JEL classification indices: O44, Q01, Q54

Frances Stewart, Emeritus Professor of Development Economics, University of Oxford, U.K. E-mail: Frances.stewart@qeh.ox.ac.uk 


\section{INTRODUCTION}

Inequality and sustainability are two issues that dominate discussions today, but are less often discussed together. Inequality, of course, is an important Kaldorian preoccupation, especially in the classic paper on the determinants of factor shares (Kaldor 1955-1956). Moreover, his massive work on tax reforms was primarily motivated by the goal of reducing inequality. Kaldor was not concerned with sustainability - it really only became a dominant preoccupation after his death. Yet today, I believe that sustainability is the most important question of the $21^{\text {st }}$ century - since the wellbeing and even the existence of future generations depend on it.

This paper explores the relationship between inequality and sustainability. It starts by defining both terms and identifying relevant criteria for determining the best distribution (Section 2). The criteria are divided into considerations of justice and of instrumentality. These are discussed in Sections 3 and 4, respectively. Section 5 takes more meta considerations into account, and Section 6 comes to some conclusions

\section{DEFINITIONS AND CRITERIA}

In assessing inequality, there are two big questions that need to be considered: inequality among whom? and inequality of what? For both questions, modifications of the usual approaches are needed if one is to focus on the sustainability issue.

Among whom? The normal classification includes individuals within a society - vertical inequality; individuals across the globe (global vertical inequality); inequality among groups (horizontal inequality); and among countries (intercountry inequality). From the perspective of the environment, each of these types of inequality are relevant, but we must add an additional one: inequality across generations (including the unborn), i.e. generational inequality.

Inequality of what? Typically, the focus of those concerned with distribution is on income, and sometimes land, or wealth more generally (e.g. Piketty 2014). However, with a broader approach to development objectives, a broader answer is needed to the "of what" question. A number of people have advocated going beyond income as the prime object: for example, Sen $(1985,1999)$ has suggested that the objective of development should be the expansion of capabilities or freedoms, or what people can be or do; others (Layard 2011; Graham 2011) have suggested that the objective should be to maximise happiness; those working on horizontal inequalities have argued that relevant dimensions of such inequali- 
ties include political power, cultural respect, and socio-economic factors (Stewart 2002, 2008). Focusing on sustainability suggests that inequality of environmental resource use and outcomes should be a prime concern. Clearly, the appropriate answer to the "of what" question depends on the purpose of analysis.

Why worry about inequality? Concern with inequality arises first from concern with justice; and secondly, instrumental issues, or how inequality affects other desired objectives. From an environmental perspective, both instrumental and justice considerations are relevant.

Economists generally tend to take an instrumental line, evaluating inequality in terms of its impact on economic growth. This was not always so. Pigou (1920) in particular advocated the distribution which would maximise a society's utility, and argued that since people have "equal capacity for satisfaction and diminishing marginal utility of income", assuming diminishing marginal utility as income increases, an egalitarian distribution would be optimal. However, Robbins (1945: 156-157) challenged the assumption of comparability of satisfaction, arguing that "in our hearts we do not regard different men's satisfactions from similar means as equally valuable". Economists broadly accepted Robbins' argument, and hence the prime focus has been on achieving a Pareto optimal situation, and therefore on inequality only as it affected output, i.e. taking an instrumental relationship with economic growth.

However, while economists take an instrumental approach, philosophers are concerned with justice: for example, Rousseau, Kant, and Rawls. As Rousseau (1762) stated:

"Whichever way we look at it, we always return to the same conclusion: ... the social pact establishes equality among the citizens in that they all pledge themselves under the same conditions and all enjoy the same rights."

The reformulation of the social contract by Rawls (2004), by which a just distribution is the distribution that people would choose if under a veil of ignorance as to their own position in the income or wealth hierarchy, led him to conclude that a just distribution would be one that maximises the position of the poorest, i.e. this justifies maximin.

As Sen (2009) points out, we do not have to know what a completely just society would look like, as long as one can see the direction of travel towards more justice. From this perspective, Rousseau and Rawls would agree that the present global and national distribution is unjust.

Considering justice, from an environmental perspective, we need to consider what is just within a country across individuals (vertical inequality), across groups (horizontal inequality) and among countries (inter-country inequality); 
and, above all, across generations. Taking an instrumental perspective, any type of inequality that affects the valued outcomes, i.e. environmental consequences, is relevant. This is an empirical issue, which we consider below.

Sustainability can be defined in many ways and there are numerous indicators. In principle, it could be interpreted as the ability to sustain a pattern of development. With this definition, we need to consider political and economic events that might impede sustained development. The extent of inequality is highly relevant (and inimical) to political and economic sustainability: see Stewart (2008) on how horizontal inequalities increase violent political conflict, and Stiglitz (2012) and Berg et al. (2008) on how vertical inequality affects economic sustainability adversely.

In this paper, sustainability is interpreted as environmental sustainability. An environmentally sustainable pattern of development is defined as one that ensures that our current behaviour does not restrict the opportunities open to future generations. There are numerous aspects of the environment, which are or may be threatened by our present economic activities, ranging from the number of natural species in the world, the fertility and productivity of the soil, and so on, to global warming which threatens many aspects of life, including ultimately life itself. To avoid too wide a canvas, in this paper the focus is on carbon emissions as the most threatening to the sustainability of long-term human wellbeing.

Environmental sustainability has been categorised into "strong" sustainability and "weak" sustainability. Weak sustainability assumes substitutability between natural capital and manufactured capital. Weak sustainability can thus be assured by a sufficient savings rate to generate non-natural capital as a substitute for the natural capital that is depleted during development (Neumayer 2010). Some substitutability is clearly possible - for example, the impact of carbon emissions can be reduced by investments in sequestration. However, the substitutability appears to be imperfect, and I shall therefore focus on strong sustainability, assuming that we should aim for an absolute limit on total global emissions. ${ }^{1}$ This is justified by scientists' reports, including the Intergovernmental Panel on Climate Change (IPCC). For example, The Living Plant Report (2014) shows:

- "Humanity's demand on the planet is more than 50\% larger than what nature can renew, jeopardizing the well-being of humans as well as populations of mammals, birds, reptiles, amphibians and fish."

- Humanity's ecological footprint more than doubled since 1961. The main source is growing carbon emissions, but also declining forests, declining species.

1 Neumayer (2010) concludes from a survey of the evidence that there is limited substitutability in relation to emissions and other forms of pollution, but reasonable substitutability for the inputs that go into the production of goods. 
- The global ecological footprint exceeds earth's renewable capacity by at least $50 \%$.

- Of the 9 ecological barriers, three have already been exceeded: bio-diversity loss, climate change, and nitrogen.

Scientists estimate that $350 \mathrm{ppm}$ (parts per million) is the "safe" level for carbon in atmosphere (Hansen et al. 2013), while $450 \mathrm{ppm}$ is an upper limit for achieving a 50:50 chance of limiting average global warming to $2^{0}$ (OECD 2012). Actual concentration recently exceeded $400 \mathrm{ppm}$ : at present rates of growth of emissions, $450 \mathrm{ppm}$ will be reached by 2030 .

Hence, here I assume a "hard" limit to total global emissions. This is highly relevant to distribution because it means that we cannot increase the emissions of the lower emitters without reducing that of the higher emitters - in contrast to assumptions about resources without a hard limit, such as incomes. The central issue then is what would be the optimal distribution of the total emissions we can allow.

To answer this, we need to return to the two issues noted above, as critical in determining the optimal distribution: what is a just distribution from an environmental perspective? And what are the instrumental effects, or how does inequality affect sustainability outcomes?

\section{JUSTICE}

We need to consider environmental justice in relation to people living today; and across generations.

\subsection{Justice across generations}

Justice across generations requires that our actions today should take into account the impact on well-being of future generations. This consideration is, of course, the major - implicit - justification for the concern with sustainability and the hard limits just discussed. Yet it is not allowed for in the way investment decisions are made, in particular the adoption of a discount rate.

A discount rate implies giving less value to benefits received by future generations than to those we get today. Because of the law of compound interest, discount rates have a large effect. For example, with a discount rate of 5.0\%, $\$ 10025$ years from now is worth just $\$ 29.5$ today, and $\$ 100$ in one hundred years would be worth three-quarters of a dollar. Hence, it is necessary to explore the justification for discounting the future. 
Justification for discounting: one reason is that we see the future less clearly than we see what happens today - Pigou called this our "telescopic vision". But this is not a justification for discounting, rather a description of what we do and value. A more rational justification is that because of economic growth, future generations will be better off, so that even with discounting, their well-being may be equivalent or better than today's. But the implications of climate change are to question this. Future generations may be much worse off, as seems quite likely on present trends. Another justification is that technology change will give future generations access to technologies that reverse or stop some of the climate change effects. But many of the climate-induced changes seem irreversible, at least for the next century or so, such as melting of the icecap or reduction of bio-diversity.

Can we apply Rawls' approach to future generations? They are clearly not part of any contemporary social contract and Rawls argued that his theory only applied within a jurisdiction with a shared government, not even across contemporary countries; the same argument might be used across generations because there is no government that includes future generations. But I reject this. As recognised by human rights approaches, every human should be treated equally, as being human. It is easy to extend Rawls' approach: behind the veil of ignorance, we may not know when we will live as well as not knowing where and in which class. Hence, we should adopt maximin across generations. This, indeed, provides the justification for the definition of environmental sustainability put forward - i.e. that our current actions should not restrict the choices of future generations.

I conclude that justice across generations makes it very difficult to justify any discounting. Yet, despite low or even negative "official" discount rates, actual borrowing rates are high, involving heavy discounting of future well-being. ${ }^{2}$ Consequently, the benefits of investments to future generations are heavily discounted.

\subsection{Justice across today's global population}

The present distributions both of the "ecological footprint"3 and of $\mathrm{CO}_{2}$ emissions per person are highly unequal across countries. Inequality in ecological footprint

2 It might be thought that the very low official rates of interest prevailing in 2016 (in some countries even negative) would lead to equally low private borrowing rates. But because of costs and risk aversion in banks, this is not the case. A review of commercial bank lending rates shows great variation ranging between 5 and $20 \%$.

3 This is an estimate of the amount of biologically productive land and water (biocapacity) needed to produce resources that an individual (or population) consumes and to absorb carbon emissions generated, with current technologies. 
is shown in the diagram below (for 2010). High-income countries are estimated to have five times the ecological footprint of low-income countries (WWF 2014).

When it comes to carbon emissions, the inequalities are extreme.

Emissions per head of low-income countries are a tiny fraction of those of rich countries (Table 1); those of middle-income countries are $38 \%$ of rich countries (although their total emissions exceed those of rich countries because of the greater population). Given the hard limits, justice could be defined as equality of emissions per head, although a somewhat different conclusion might emerge with maximin, given different ratios of emissions to output. Moreover, we must note that these estimates do not allow for the emissions associated with consumption (consumption of imports), but are emissions of production, and much of rich

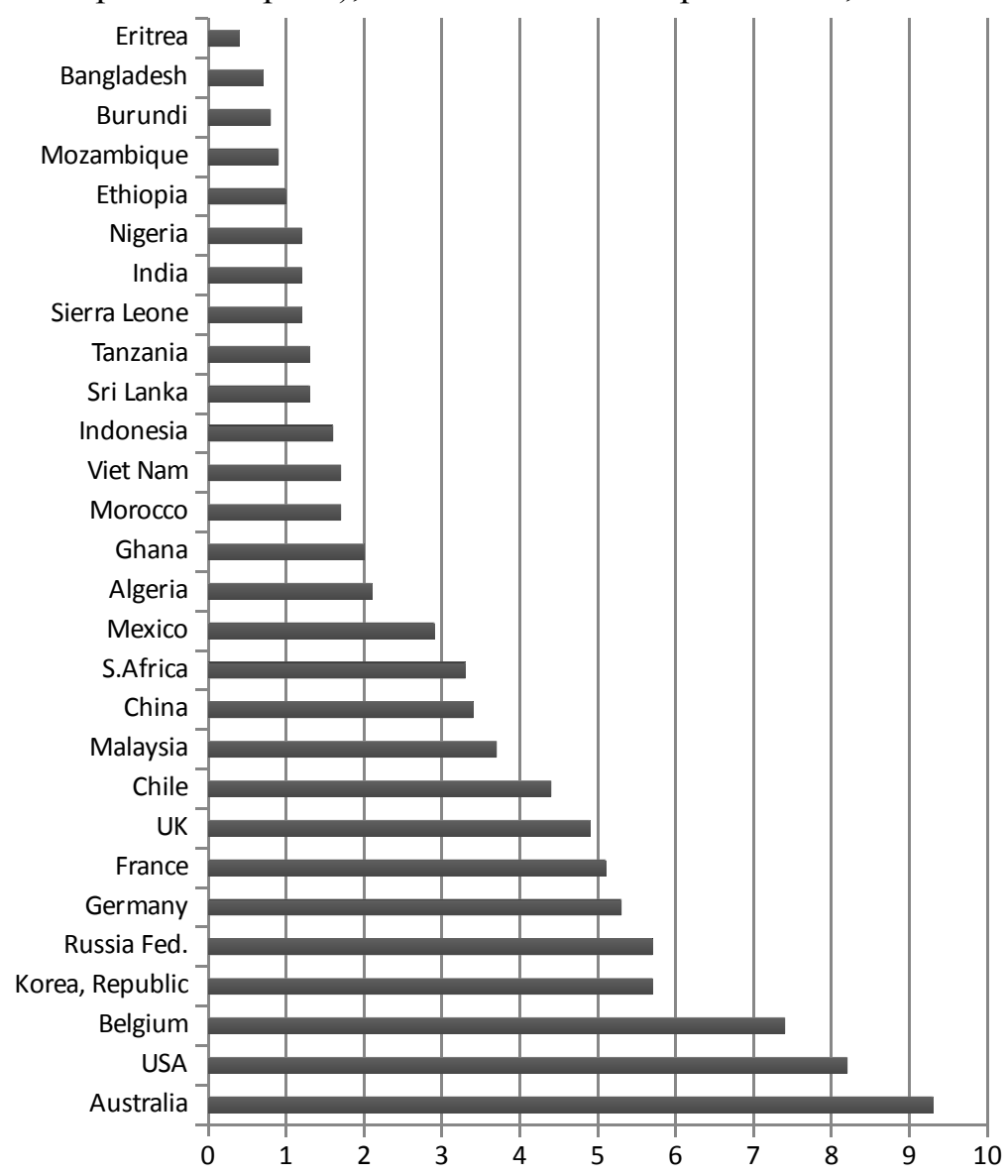

Figure 1. Ecological footprint per person, selected countries, 2012 (global hectares) Source: Global Footprint Network. 
Table 1. The global picture of production emissions, 2010

\begin{tabular}{l|c|c|c|c|c}
\hline Countries & $\begin{array}{c}\text { Population, } \\
\text { million }\end{array}$ & $\begin{array}{c}\text { Output per } \\
\text { head, \$ }\end{array}$ & $\begin{array}{c}\text { Emissions per unit } \\
\text { of output } \\
\left(\mathrm{CO}_{2} \text { metric tons }\right. \\
\text { per \$ of output } \\
\mathrm{E} / \mathrm{O}\end{array}$ & $\begin{array}{c}\text { Total emissions } \\
\text { of production, } \\
\mathrm{kt}(1000 \mathrm{t})\end{array}$ & $\begin{array}{c}\text { Emissions } \\
\text { per head, } \\
\mathrm{kt} \\
\mathrm{E} / \mathrm{P}\end{array}$ \\
\hline Rich & 1,287 & 34,927 & 0.4 & 17,980 & 13,970 \\
\hline Middle-income & 4,788 & 3,792 & 1.4 & 25,418 & 5,309 \\
\hline Low-income & 810 & 515 & 0.7 & 289 & 356 \\
\hline World & 6,885 & 9,224 & 0.7 & 43,724 & 6,350 \\
\hline
\end{tabular}

Source: World Bank, World Development Indicators.

Note: We use World Bank classification of countries into different income groups.

countries' consumption of carbon-intensive manufactures come from middleincome countries.

The conclusion must be that environmental justice requires far less inequality in emissions than observed today, without defining precisely what a just distribution would look like. This, in turn, implies massively more egalitarian income distribution since there is a close association between income per capita and emissions. For 2007, the ecological footprint (which is consumption-based) of the richest third countries was 5.5 global hectares per person, the middle third was 2.4 and the poorest third 1.4 (calculated from Ewing et al. 2010). ${ }^{4}$

Unfortunately, actions are rarely determined by considerations of justice; instrumental arguments tend to be more powerful. Hence, we now turn to instrumental issues. The basic question is: given hard limit on emissions, what distribution of income is likely to contribute to reducing emissions?

\section{INSTRUMENTALITY}

The instrumental arguments concern how distribution of incomes affects global sustainability. Does more inequality increase or reduce emissions? Arguments have been put forward on both sides. For example, Ravaillon et al. (2000: 651)

$4 \quad$ "A global hectare is a common unit that encompasses the average productivity of all the biologically productive land and sea area in the world in a given year. ... The Footprint tracks current human demand on nature in terms of the area required to supply the resources used and absorb the $\mathrm{CO} 2$ emitted in providing goods and services. Trade is accounted for by allocating this demand to the country that ultimately consumes these goods and services". (http:/ www.footprintnetwork.org/en/index.php/GFN/page/frequently_asked_questions/\#method2: accessed September 19, 2016). 
argue that "Higher inequality, both between and within countries is associated with lower emissions at given average incomes".

In diametric disagreement, Boyce (1994) and Torras - Boyce (1998) hypothesise that the more unequally power (and income) is distributed, the greater the pollution:

"The total magnitude of environmental harm depends on the extent of inequality. Societies with wider inequalities of wealth and power will tend to have more environmental harm. Conversely, societies with relatively modest degrees of economic and political disparities will tend to have less environmental harm" (Boyce 1994: 7-8).

The main justification advanced for the hypothesis that higher inequality reduces emissions is that the desire to reduce emissions (the marginal propensity to emit - MPE) rises with income (it is a type of luxury good) and this translates into consumer choices (more services, fewer material goods) and into political support for regulations. Ravallion et al. cite Dasgupta et al.'s (1995) 31 country study showing that rising income increased the demand for regulation. Changing MPE can be due to changing patterns of consumption - for example, increasing the proportion of expenditure on services, which involves lower emissions than material goods. On the other hand, Boyce and others argue that because the poor suffer the main consequences of pollution, while the rich bear most of the costs of policies to control it, there are powerful political economy reasons for expecting more unequal societies (with inequality in political power and incomes assumed to be highly correlated) to take less action in relation to pollution than more equal ones. Thus, Boyce argues that more equal societies would be more regulatory, while Ravallion et al. argue the opposite - that they would be less regulatory than more unequal societies.

Both types of arguments can be interpreted to apply to inter-country as well as intra-country distribution. Both are dependent on empirical assumptions about consumer behaviour and political power. It seems plausible that both overgeneralise. For example, it is arguable that the MPE may be higher for middleincome countries than for low-income ones since their production and consumption is increasingly composed of material goods, and then it may decline for the richest countries. The same might be true within societies. In addition, within societies, variations in the MPE by income group might vary according to the average incomes of the society.

To shed light on which of these positions is correct, i.e. whether emissions rise or fall according to the distribution of incomes, we need to turn to the empirical evidence. 


\subsection{Inter-country evidence}

Table 1 above showed that average emissions per unit of output is lowest in highincome countries and highest in middle-income countries. However, as noted, these are measures based on production, not consumption. As rich countries import many material goods from middle-income ones, consumption adjusted ratios would reduce the middle-income and raise the high-income ratio. Yet estimates of the ecological footprint per unit of output also show high-income countries with the lowest ratio. Hence, if the average is a guide to the marginal, then minimising emissions would actually require regressive redistribution across countries. This is reflected in what has come to be known as the Environmental Kuznets Curve (EKC) (Grossman - Kruger 1995; Selden - Song 1994; Shafik 1994), in which, according to some authors, pollutants peak, in absolute terms, at about average world income. However, Grossman - Kruger (1995) do not include carbon emissions, but explore local pollutants; Shafik (1994) finds that the relationship varies according to the pollutant, and in relation to carbon emissions, there is a continuous increase with rising per capita incomes, while Selden - Song (1994) find that for carbon emissions, the quadratic term, while negative is not significant. Yet Constantini Martini (2006) find a significant Kuznets relationship for emissions. Ravallion et al. (2000) estimate that transferring 5\% from the income of the richest five countries to the poorest five countries would increase emissions by $2.4 \%$. These studies relate to the late 1990 s and early 2000 s, and are based on production.

Like the original Kuznets curve, the relationship identified is between levels of income per capita and emissions per capita - i.e. average, not marginal emissions in relation to output. Grubb et al. (1999) explored the relationship between growth and emissions, and found that the US and UK had almost constant emissions per head 1950-1995, despite growth in GDP per capita. But there was a strong relationship between growth in income and in emissions in middle-income industrialising countries. A study of 69 countries for 2000-2014 found 35 countries (all high-income) which reduced their emissions while growing (CarbonBrief

Table 2. $\mathrm{CO}_{2}$ change by income level, 2000-2014

\begin{tabular}{l|c|c|c|c}
\hline Countries & $\mathrm{CO}_{2}$ change, $\mathrm{Mt}$ & $\mathrm{CO}_{2}$ change, $\%$ & GDP change, \% & $\begin{array}{c}\text { Intensity }\left(\mathrm{CO}_{2} /\right. \\
\text { GDP) change, } \%\end{array}$ \\
\hline $\begin{array}{l}\text { Average low- } \\
\text { income }\end{array}$ & 4.76 & 1.38 & 1.05 & 0.29 \\
\hline $\begin{array}{l}\text { Average middle- } \\
\text { income }\end{array}$ & 169.16 & 0.90 & 1.03 & -0.02 \\
\hline $\begin{array}{l}\text { Average high- } \\
\text { income }\end{array}$ & 9.97 & 0.29 & 0.50 & -0.12 \\
\hline
\end{tabular}

Source: Derived from Carbon Brief data. 
2016). A much larger sample, 216 countries, found 21 (again all high-income) cut their emissions while growing between 2000-2013, using a consumption-based measure. Low-income countries showed an increase in carbon-intensity (from a very low level), middle-income countries' intensity was roughly stable, and high-income countries' intensity fell, though for the world as a whole emissions rose (Table 2). This information suggests that increasing inter-country inequality would reduce emissions. However, the data do not actually measure the MPE, or elasticity of emissions with respect to income growth, as the change in emissions could be due to technology change affecting all production, and growth at the margin may increase emissions by more (Stavins 2016).

\subsection{Within country inequality}

In a cross-country study of 42 countries for the years 1975-1992, Ravallion et al. (2000) shows that higher income inequality reduces emissions, but the impact is smaller at higher average income levels. Economic growth also reduces the adverse impact of higher inequality on emissions. Heerink et al. (2001) come to similar findings: greater inequality is associated with lower emissions. But others have found no significant impact, for example Borghese (2006) and Lamla - Stern (2010). Later studies have identified more complex relationships. Grunewald et al. (2012) find for 1960-2008 that increasing inequality decreases emissions in relatively equal countries, but the opposite prevails in very unequal ones. These studies are all production-based. Using a consumption-based indicator of emissions, Jorgenson et al. (2016) show that the relationships vary across countries and time for 67 countries between 1991-2008. Inequality in high-income countries was negatively associated with emissions, but the association became positive; for middle-income countries, there was a consistent and increasing negative effect, so that more inequality reduced emissions; and for low-income countries, there was no relationship.

Results appear to differ for other environmental indicators. For example, Torras - Boyce (1998) find support for Boyce's (1994) claims that greater inequality in political power increases pollution, with data from US states in the 1990s using a general index of environmental stress. However, this is questioned by Scruggs (1998) using cross-country data, who finds that the association between political and economic inequality and the environment varies according to the environmental indicator adopted, and concludes: "On the whole, this evidence refutes the equality hypothesis. Once the income effects predicted by standard economics are controlled for, neither income inequality nor political inequality have consistently discernible effects on the environmental quality indicators considered here" 
(p. 268). However, in line with the Boyce hypothesis, Mikkelson et al. (2007) find that greater income inequality is associated with loss in biodiversity across countries and among US states.

There seem to be few studies of distribution and emissions in specific countries. However, investigating the impact of income on emissions among urban households in China, Golley - Meng (2012) find that higher income households generate more emissions than lower income ones, with a slightly increasing MPE, so that redistribution would reduce emissions.

What can we conclude from these rather complex and conflicting results?

- Most evidence on inter-country distribution suggests that more equal distribution is likely to increase emissions.

- For intra-country distribution:

- Neither the Ravallion, nor the (opposite) Boyce hypotheses are firmly established. However, on carbon emissions, most studies show that greater inequality reduces emissions, particularly in middle-income countries - although this is contradicted by the China study.

- Nonetheless, the perverse results (from a justice perspective) seem to be moderated for high-income countries and may differ for high inequality and low inequality countries.

- For non-carbon pollution, the few studies show a negative relationship between inequality and environmental degradation (i.e. no trade-off between reducing pollution and justice).

- The relationships seem to be changing over time. This suggests potential for affecting the relationships by deliberate policy to that effect.

\section{MORE MACRO OR META CONSIDERATIONS}

Up to now, the paper has focused on how the MPE might be affected by inter- and intra-country distribution, given present growth ambitions and global regulations. Yet these two elements are critical for $\mathrm{CO}_{2}$ outcomes, and in turn are probably affected by distribution.

\subsection{The growth motive}

A major cause of rising emissions is economic growth, as the following tautology indicates (a modification of the IPAT equation of Erlich - Holdren ${ }^{5}$ ):

$5 \quad$ Adapted by many, including Commoner 1972 and Speth 1990. 
$\mathrm{E}=\mathrm{P} \times \mathrm{O} / \mathrm{P} \times \mathrm{E} / \mathrm{O}$

In this equation, total emissions (E) are equivalent to:

- Population size (P) times

- Output per head $(\mathrm{O} / \mathrm{P})$ times

- Emissions per unit of output (E/O).

Technology (here represented by E/O) is improving, as shown earlier, and population growth is slowing in the world as a whole and in most countries. It remains the case, however, that at any point in time, when population growth rate and technology change is given, emissions growth is determined by growth in output per head. This is broadly indicated by the way in which emissions reflect output growth, as shown in Figure 2. Above we noted that some countries (21 out of 256) managed to reduce $\mathrm{CO}_{2}$ while experiencing growth of incomes, yet this does not detract from the basic relationship between growth and emissions while it shows that technology is improving, for the technology available at a point in time the higher the growth the more the emissions (Stavins 2016). Only if the technology improvement depended entirely on additional output would this link be broken.

We need therefore to consider why countries give such emphasis to economic growth. For countries with massive absolute poverty, the elimination of poverty is a major element in motivation - but one that could clearly be more quickly

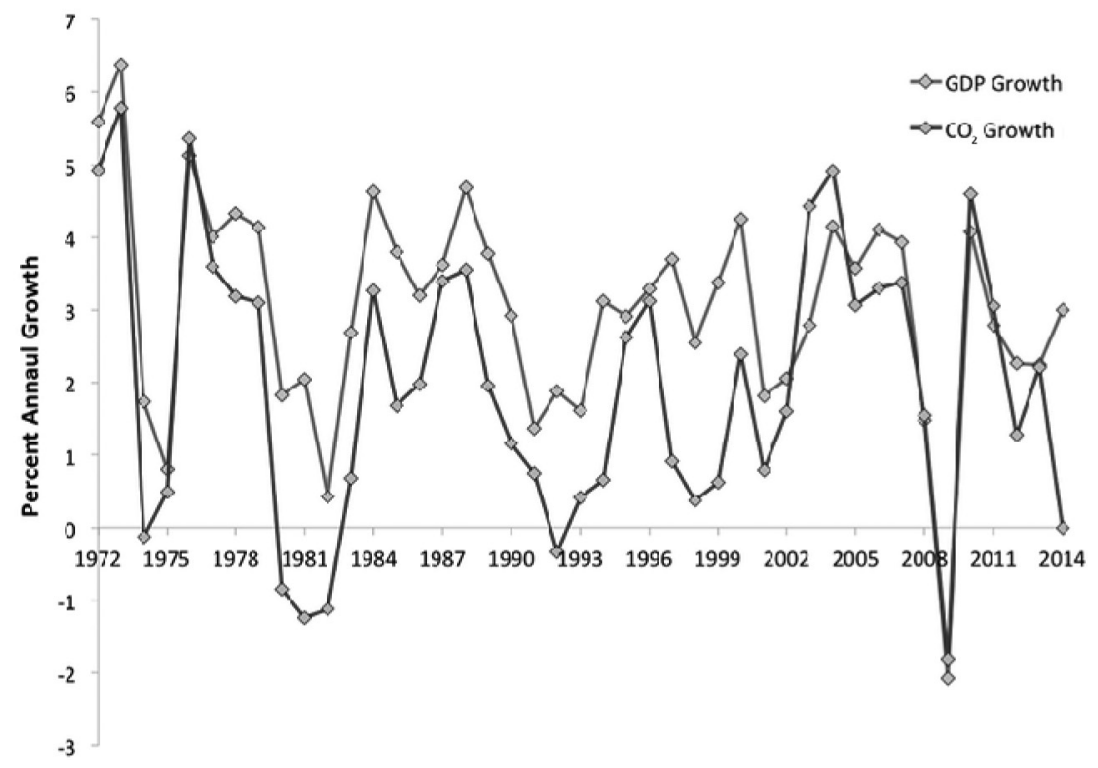

Figure 2. Global annual GDP growth vs. $\mathrm{CO}_{2}$ emissions growth Source: Nuticelli (2015), derived from World Bank and International Energy Agency data. 
achieved if growth were accompanied by redistribution. For other countries, where absolute poverty has been eliminated - i.e. upper-middle and high-income countries - a major motive is to "catch-up" with higher-income countries. Yet for middle-income countries to catch-up with the existing levels of per capita income of high-income countries itself involves huge increases in emissions.

If low- and middle-income countries grew enough to catch up with the present level of emissions of rich countries, and adopted the technology currently used by rich countries, global emissions would more than double. The additional emissions on these assumptions would be $47,700 \mathrm{kt}$, which is equivalent to 1.4 times present emissions. As noted earlier, the present concentration of carbon in the atmosphere is already above the level some consider as safe.

Consequently, the catch-up scenario to the present levels of income of rich countries, on the basis of current technology, involves a non-sustainable level of global emissions. Moreover, the rich countries' output will also continue to grow with present policies, increasing the catch-up target. Probably the biggest source of unsustainable emissions in the medium term stems from the process of catch-up.

Redistribution of income across countries would help catch up. Indeed, complete convergence could be attained without any rise in emissions, by sharing incomes evenly across the world. Average global income is around $\$ 10,000$, which is way above any poverty line, and this is the level that would be achieved by distributing income evenly across the countries of the world. Countries with average incomes of $\$ 10,000$ include Costa Rica, Lebanon, Panama and Turkey, all of which have basically eliminated poverty. A level of income of $\$ 10,000$ per head is more than double that of middle-income countries as a group, and is $36 \%$ more than upper middle-income countries. Such radical redistribution would fulfil Raworth's doughnut requirements - i.e. a pattern of world development that respected environmental limits imposed by tipping points in critical earth system processes and achieved the social goal of eliminating poverty in its various dimensions (Raworth 2012). ${ }^{6}$

Within country inequality and the catch-up motive, provide another reason for pursuing economic growth, including in rich countries. Each income class wants to achieve the standards of those with higher standards in their own society. In the absence of domestic redistribution, growth of output provides a partial solution, allowing (in principle) rising standards at all levels. Insofar as people's wellbeing is related to their position relative to others in society, continuous growth is needed even to keep in the same place. At the same time, richer classes promote growth so that they can meet the demands of lower-income groups for rising incomes without redistribution. Yet for higher-income countries, economic growth

$6 \quad$ Raworth's doughnut includes nine planetary boundaries and eleven social boundaries. 
does not appear to increase happiness or fulfilment (Easterlin 1974; Skidelsky - Skidelsky 2012).

Redistribution within economies would permit poorer groups to catch up with richer ones and thus obviate the demand for growth. Inequality and the desire to catch up explains the paradox that every country, however well off, wants to grow, despite the evidence that growth does not increase well-being or happiness and is environmentally damaging.

\subsection{International agreements}

International agreements to regulate emissions obviously have a huge potential, as they impose equal costs on all participants in international trade and thus obviate the competitive incentive to maintain emissions. Would a more equal world be more likely to support such regulations?

In the literature on regulation of the commons, arguments can be found on both sides: on the one hand, greater equality tends to increase trust and social cohesion, and this is likely to make collective agreements more likely. This may be combined with Boyce's proposition that the rich (and powerful) bear the costs of regulation and the poor the costs of lack of regulation, so that a world where income and power is more evenly shared would be more likely to reach regulatory agreement. In addition, heterogeneity (of wealth, ethnicity, etc.) is often claimed to be an obstacle to reaching regulatory agreements (Varughese - Ostrom 2001).

On the other side of the argument, where all agents are "rational", each must be convinced that they would suffer enough from non-regulation to justify the costs to them. A few very rich actors with a large share of output may be convinced that it is in their own interests to regulate the commons, but with many equal agents collective action is more problematic, as individually each gains by not regulating (Olson 1965). Evidence from agreements to regulate the commons within countries has been advanced on both sides of the argument. Koop - Tole (2001) find that the negative impact of development on deforestation is less where inequality is less. Surveying many arrangements to protect the commons, Baland - Platteau (2007) find inequality makes regulation less acceptable, although they find no systematic relationship in unregulated settings. Others suggest that substantial inequality is a bar to action, but some inequality helps (Baker 1998; Molinas 1998).

Putting the argument into a global context where countries are the agents involved, across countries there is considerable heterogeneity of nationality, religion, and ethnicity as well as of income, which makes it difficult for countries to recognise and value a common global interest. The unavoidable heterogeneity 
of this kind is compounded by the heterogeneity of incomes. Poorer nations are loath to come to an agreement that will limit their ability to catch up, particularly when the vast mass of emissions has been caused by the historic actions of the richer countries. As Varughese - Ostrom (2001) argue, in the context of microarrangements, institutions can overcome heterogeneity. High inequality among nations makes it difficult to agree on and secure respect for such institutions. While very large nations might, Olson-style, try to impose institutions and regulations, these may well be thwarted so long as lower-income countries feel they are unfair. This conclusion is broadly reflected in the slow progress of global negotiations on action for climate change, made even more problematic by the pressures from carbon-producing industries. I would conclude that substantially more equality between nations would make effective global agreement on regulation much more likely.

\section{CONCLUSIONS}

The issue of sustainability raises major issues of justice across and within generations. The "across" generation issue means we must limit total current emissions; this limit implies that a just distribution would involve equalisation of rights to emit within and across countries. This might be in conflict with the findings of what the most efficient distribution of emissions would be across and within countries - given that the evidence suggests that richer people and countries may have a lower MPE than poorer ones. Yet two further meta-arguments challenge this: first, the catch-up motive for growth, which would be modified with more equal distribution, consequently potentially reducing growth-related emissions; and secondly, the enhanced likelihood of coming to an enforceable global agreement to limit emissions with more equality. The latter argument derives from the need for a sense of common global purpose, which is more likely to emerge with more equality across and within nations.

Finally, I return to the issue of how Kaldor might have viewed these questions. Undoubtedly, he would have agreed with the conclusions. But I think it is likely that he would have focused more on technology and the relationship between "solving" the emissions problem by technology without abandoning growth. After all, endogeneity of technology was one of his fundamental insights. 


\section{REFERENCES}

Baker, J. M. (1998): The Effect of Community Structure on Social Forestry Outcomes: Insights from Chota Nagpur, India. Mountain Research and Development, 18(1): 51-62.

Baland, J. M. - Platteau, J. P. (2007): The Ambiguous Impact of Inequality on Local Resoruce Management. World Development, 27(5): 773-788.

Berg, A. - Ostry, J. D. - Zettelmeyer, J. (2008): What Makes Growth Sustained? IMF Working Paper, No. 59, Washington, D. C.

Borghese, S. (2006): Income Inequality and the Environmental Kuznets Curve. In: Franzini, M. Vercelli, A. (eds): Environment, Inequality and Collectvie Action. New York: Routledge.

Boyce, J. K. (1994): In Equality as a Cause of Environmental Degradation. Ecological Economics, 11(3): 169-178.

Boyce, J. K. (2007): Is Inequality Bad for the Environment? Working Paper Series, No. 135. Amherst, University of Massachusetts, Political Economy Research Institute (PERI).

Carbonbrief (2016): The 35 Countries Cutting the Link Between Economic Growth and Emissions. https://www.carbonbrief.org/the-35-countries-cutting-the-link-between-economic-growth-andemissions.

Commoner, B. (1972): A Bulletin Dialogue on "The Closing Circle": Response. Bulletin of the Atomic Scientists, 28(5): 42-56.

Costantini, V. - Martini, C. (2006): A Modified Environmental Kuznets Curve for Sustainable Development Assessment Usingpanel Data. Working Paper, No. 148. Department of Economics, Roma Tre University.

Dasgupta, S. - Mody, A. - Roy, S. - Wheeler, D. (1995): Environmental Regulation and Develoment: A Cross-Country Empirical Analysis. World Bank Policy Research Working Paper, No. 1448. Washington, D. C.

Easterlin, R. A. (1974): Does Economic Growth Improve the Human Lot? Some Empirical Evidence. In: David, P. - Reder, M. (eds): Nations and Households in Economic Growth. New York: Academic Press, pp. 89-125.

Ehrlich, P. R. - Holdren, J. (1971): Impact of Population Growth. Science, 171(3977): 1212-1217.

Ewing, B. - Moore, D. - Goldfinger, S. - Oursler, A. - Reed, A. - Wackernage, M. (2010): The Ecological Footprint Atlas 2010. Oakland: Global Footprint Network.

Golley, J. - Meng, X. (2012): Income Inequality and Carbo Doxide Emissions: The Case of Chinese Uran Households. Energy Economics, 34(6): 1864-1872.

Graham, C. (2011): The Pursuit of Happiness an Economy of Well-Being. Washington, D.C.: Brookings Institution Press.

Grossman, G. M. - Kruger, A. B. (1995): Economic Growth and the Environment. Quarterly Journal of Economics, 110(2): 353-377.

Grubb, M. - Müller, B. - Butler, L. (1999): The Relationship between Carbon Dioxide Emissions and Economic Growth. Oxbridge Study on $\mathrm{Co}_{2}$-GDP Relationships, Phase 1 Results. Cambridge University, Department of Applied Economics.

Grunewald, N. - Klasen, S. - Marinez-Zarzosa, I. - Muris, C. (2012): Income Inequality and Carbon Emissions. Discussion Paper 92. Courant Research Centre, University of Gottingen.

Hansen, J. et al. (2013): Assessing "Dangerous Climate Change": Required Reduction of Carbon Emissions to Protect Young People, Future Generations and Nature. Plos ONE, 8(12): http:// dx.doi.org/10.1371/journal.pone.0081648

Heerink, N. - Mulatu, A. - Bulte, E. (2001): Income Inequality and the Enrvionment: Aggregation Bias in Environmental Kuznets Curves. Ecological Economics, 38(3): 359-367. 
Jorgenson, A. K. - Schor, J. B. - Knight, K. W. - Huang, X. (2016): Domestic Inequality and Carbon Emissions in Comparative Perspective. Sociological Forum, 31(1): 770-786.

Kaldor, N. (1955-1956): Alternative Theories of Distribution. The Review of Economic Studies, 23(2): 83-100.

Koop, G. - Tole, L. (2001): Deforestation, Distribution and Development. Global Environmental Change, 11(3): 193-202.

Layard, R. (2011): Happiness (Revised edition). London: Penguin.

Mikkelson, G. M. - Gonzalez, A. - Peterson, G. D. (2007): Economic Inequality Predicts Biodiversity Loss. Plos ONE, 2(5): e444. doi:10.1371/journal.pone.0000444.

Molinas, J. R. (1998): The Impact of Inequality, Gender, External Assistance and Social Capital on Local-Level Collective Action. World Development, 26(3): 413-431.

Neumayer, E. (2010): Weak Versus Strong Sustainability. Exploring The Limits of Two Opposing Paradigms. Cheltenham: Edward Elgar.

Nuccitelli, D. (2015): Fossil Fels are more Expensive than You Think. The Guardian, 18 March.

OECD (2012): The OECD Environmental Outlook to 2050. Key Findings on Climate Change [Online]. http://www.oecd.org/env/cc/outlook to 2050_climate change chapter_higlights-fina-8pager-updated nov2012.pdf. [Accessed September 11, 2016.

Olson, M. (1965): The Logic of Collective Action. Cambridge, Mass.: Harvard University Press.

Pigou, A. C. (1920): The Economics of Welfare. London: Macmillan.

Piketty, T. (2014): Capital in the Twenty-First Century. Cambridge, Mass.: Belknap Press of Harvard University Press.

Ravallion, M. - Heil, M. - Jalan, J. (2000): Carbon Emissions and Income Inequality. Oxford Economic Papers, 52(4): 651-669.

Rawls, J. (2004): Justice as Fairness: A Restatement. Delhi: Universal Law Publishing Co. Ltd.

Raworth, K. (2012): A Safe and Just Space for Humanity: Can We Live inside the Doughnut. OXFAM Discussion Papers. Oxford.

Robbins, L. R. B. (1945): An Essay on the Nature and Significance of Economic Science (Second edition). London: Macmillan.

Rousseau, J. J. (1968, first edition 1762): The Social Contract. London: Penguin.

Scruggs, L. A. (1998): Political and Economic Inequality and the Environment. Ecological Economics, 26(3): 259-275.

Selden, T. - Song, D. (1994): Environmental Quality and Development: Is there a Kuznets Curve for Air Polluti Emissions? Journal of Environmental Economics and Management, 27(2): 147162.

Sen, A. K. (1985): Commodities and Capabilities. Amsterdam: North-Holland.

Sen, A. K. (1999): Development as Freedom (Daf). Oxford: Oxford University Press.

Sen, A. K. (2009): The Idea of Justice. London: Allen Lane.

Shafik, N. (1994): Economic Development and Environmental Quality: An Econometric Analysis. Oxford Economic Papers, 46 (S): 147-162.

Skidelsky, R. - Skidelsky, E. (2012): How Much is Enough? The Love of Money and the Case for the Good Life. London: Allen Lane.

Speth, J. (1990): Needed: An Environmental Revolution in Technology. Background Paper Prepared for a Symposium: Toward 2000: Environment, Technology and the New Century. World Resources Institute, June 13-15.

Stavins, R. (2016): Misleading Talk about Decoupling $\mathrm{CO}_{2}$ Emissions and Economic Growth [Online]. http://www.robertstavinsblog.org/misleading-talk-about-decoupling-co2emissionsand-eonomic-growth. 
Stewart, F. (2002): Horizontal Inequality: A Neglected Dimension of Development. Helsinki: WIDER Annual Development Lecture 2001.

Stewart, F. (ed.) (2008): Horizontal Inequalities and Conflict: Understanding Group Violence in Multiethnic Societies. London: Palgrave.

Stiglitz, J. E. (2012): Macro-Economic Fluctuations, Inequality and Human Development. Journal of Human Development and Capabilities, 13(1): 31-58.

Torras, M. - Boyce, J. K. (1998): Income, Inequality and Pollution: A Reassment of the Environmental Kuznets Curve. Ecological Economics, 25(2): 147-160.

Varughese, G. - Ostrom, E. (2001): The Contested Role of Heterogeneity in Collective Action: Some Evidence from Community Forestry in Nepal. World Development, 29(5): 747-756.

Word Wide Fund for Nature (WWF): Living Planet Report 2014. http://www.worldwildlife.org/ pages/living-planet-report-2014. [Accessed September 11, 2016.] 